\title{
Influence of polymorphism of the kappa-casein gene of cows on the development of calves in the early postnatal period
}

\author{
Olga Polozyuk ${ }^{1, *}$, Margarita Zabelina², Tatiana Preobrazhenskaya ${ }^{2}$, Igor Tyurin ${ }^{2}$, and \\ Elena Lakota $^{3}$ \\ ${ }^{1}$ FSBEI HE Don State Agrarian University, st. Michurina, 39/1, Persianovsky settlement, 346493 \\ Oktyabrsky District, Rostov Region, \\ ${ }^{2}$ FSBEI HE Saratov State Agrarian University named after N. I. Vavilov, Teatralnaya sq. 1, 410012 \\ Saratov \\ ${ }^{3}$ FSBRI "Federal Agrarian Scientific Center of the South-East", st. Tulaykova, 7, 410010 Saratov
}

\begin{abstract}
The authors found that the density of colostrum in cows with a homozygous genotype for the B allele of the kappa-casein gene was higher compared to the homozygous genotype for the A allele and had a greater amount of immunoglobulins by $29.5 \mathrm{mg} / \mathrm{l}$, respectively. The formation of high colostral immunity in calves obtained from cows of mothers of genotypes $\mathrm{AB}$ and $\mathrm{BB}$ prevented the occurrence of diseases of the gastrointestinal tract, and in calves obtained from mothers of genotype AA genotype kappa-casein with a reduced amount of immunoglobulins in colostrum, it led to the development of diarrhea in $12 \%$ of newborn calves. The dynamics of the live weight of calves obtained from cows of mothers with the AA genotype of the kappa-casein gene, during the first 30 days of life, was 6.34 and $4.78 \mathrm{~kg}$ lower than in young cows with the $\mathrm{BB}$ and $\mathrm{AB}$ genotypes of the kappa-casein gene. At the age of one month, the leukocyte content in calves obtained from cows from mothers with a homozygous genotype for allele A of the kappa-casein gene was less by 10.8 and $16.2 \%$, and hemoglobin by 10.5 and $10.7 \%$.
\end{abstract}

\section{Introduction}

Assessment of the accuracy of the breeding value of an animal largely depends on the efficiency of selection and breeding work in animal husbandry. The introduction of molecular genetics into applied science made it possible to assess the genetic potential of animal productivity not only on the basis of the phenotype, but also at the DNA level. When using traditional breeding methods, there is a great danger of a decrease in the breed, herds, lines, families of genetic diversity, which significantly affects not only productivity and reproduction, but also sharply limits the adaptability of an individual to the conditions of keeping and viability of the resulting offspring.

\footnotetext{
${ }^{*}$ Corresponding author: polozyuk7@mail.ru
} 
The use of DNA markers makes it possible to assess animals at the level of the hereditary inclinations of the organism, since the use of selection for genetic markers brings selection to a new level, allowing direct assessment of genotypes [1-6].

The creation of genomic databases allows for a quick search for information on localized genetic markers in a particular animal species, displays the general picture of the study of genomes, including information on mutant phenotypes. Knowing the nucleotide sequence and localization of a specific marker, it is possible to identify polymorphic regions, which subsequently makes it possible to establish a connection between the polymorphic variant and one or another economically useful trait, intrauterine pathology, neonatal disease, etc. [7-11]. One of the genes that control the quality of milk is the gene for kappa-casein, since the amount of immunoglobulins depends on its density. In this regard, it is an important selection criterion for dairy cattle breeds in terms of dairy production and enhancing the safety of newborn young animals [12].

Therefore, obtaining healthy young animals, resistant to diseases, unfavorable conditions of keeping, capable of realizing their genetic potential in the breeding process, is urgent.

The aim of the research was to examine Holsteinized black-and-white cows for the presence of a mutation in the kappa-casein gene, followed by the effect of immunoglobulins of the first portion of colostrum on the growth and development of newborn calves.

\section{Material and methods}

The experimental part of the work was performed in the conditions of the MatveevoKurgan district of the Rostov region on the basis of the MTF in LLC "Leninskoe Znamya" on Holsteinized black-and-white cows, as well as calves obtained from them. The cows were similar in calving season, age, live weight. The conditions of detention were the same. The frequency of occurrence of allelic variants of the kappa-casein gene was performed using PCR-RFLP methods.

For this study, 60 cows were tested during the dry period. For DNA genotyping, blood was taken from the tail vein into special vacuum tubes for PCR studies, which were placed in a thermos - refrigerator and delivered for research to the laboratory of molecular diagnostics and biotechnology of the regional laboratory. Amplification of the kappa-casein gene fragment was performed by PCR [13]. Based on the results of DNA genotyping, the influence of the cow's genotype for the kappa-casein gene on the immunoglobulin content of the first portion of colostrum and its effect on the development of newborn calves was assessed.

Throughout the experiment, as calves were born, the concentration of immunoglobulins in colostrum was determined by the kappa-casein gene in fresh cows of different genotypes in the first hours after calving. For this, before the first feeding of colostrum to the calf, colostrum was milked from fresh cows, and its density was determined using a lacto densimeter. The determination was performed by immersing the lacto densimeter in colostrum, previously poured into a cylinder with divisions from 1.020 to 1.080 . The immersion mark was the density of the milk.

Determination of immunoglobulins in the blood serum of newborn calves was performed by the end of the first day after birth. In newborns, the amount of serum immunoglobulins was determined using a manual milk refractometer (MMR). For this, the blood of their jugular vein was taken into a test tube and placed in warm water, while the blood was standing. After that, a drop of serum was placed on a refractometer and the result was determined using a scale. 
The first eight days after calving, newborn calves received three times colostrum from mothers cows, and then, up to 30 days of age, were fed with bulk whole milk pursuant to the drinking scheme approved by the farm. Newborn calves up to 8 days of age were kept in separate boxes for no more than 4 heads, the age difference in birth in each box was 2 days. Boxes for keeping newborn calves were filled on the principle "everything is empty everything is busy". After the transfer of the calves to the calf shed of the dispensary, mechanical cleaning, disinfection and bactericidal ultraviolet irradiation of the box were performed.

Morphological parameters: the concentration of hemoglobin was determined on a photoelectric calorimeter, the number of erythrocytes and leukocytes in the Goryaev chamber. Blood for research was taken from calves from the jugular vein in the morning at the same time, before feeding the animals on the 2 nd and 30th days of life.

\section{Results and discussion}

According to the results of DNA testing performed by the researchers, three variants of the genotype were identified - $\mathrm{AA}, \mathrm{AB}, \mathrm{BB}$, which have different frequencies of occurrence [14].

After DNA genotyping in 60 cows during the dry period, it was found (Table 1) that the frequency of individuals with the $\mathrm{AB}$ genotype was the most common, which was 63.3. In contrast to the $\mathrm{AB}$ genotype, cows with the $\mathrm{BB}$ genotype were encountered much less frequently, only $6.7 \%$.

Table 1. Frequency of genotypes in cows by polymorphism of kappa-casein genes.

\begin{tabular}{|l|c|c|c|}
\hline \multirow{2}{*}{ Breed } & \multicolumn{3}{|c|}{ Genotypes } \\
\cline { 2 - 4 } & AA & AB & BB \\
\hline Holstein- & \multicolumn{3}{|c|}{ Genotype frequency, animals } \\
\cline { 2 - 4 } Frisian & 18 & \multicolumn{3}{|c|}{4} \\
\hline Holstein- & \multicolumn{3}{|c|}{ Genotype frequency, \% } \\
Frisian & 30 & 63.3 & 6.7 \\
\hline
\end{tabular}

After birth, the only food for calves is colostrum. In this case, colostrum, during the transition of the calf from placental nutrition to nutrition in the environment, is the main link. Only in the first 24 hours after birth, the calf receives antibodies with the mother's colostrum, which are freely absorbed into the blood through the integumentary epithelium of the small intestine, and the amount of immunoglobulins that enter the body will determine its ability to respond to pathogenic agents. This is due to the fact that colostrum has a bactericidal effect, since it contains lysozyme, a substance capable of dissolving the membranes of microorganisms, as well as functionally active leukocytes and lymphocytes. Herewith, colostrum creates an acidic environment in the abomasum, as it has an increased acidity, which has a detrimental effect on conditionally pathogenic and pathogenic microflora, which prevents the development of putrefactive processes. Colostral route with colostrum is transmitted to newborns with autoantibodies and sensitized lymphocytes against certain cellular, tissue and organ antigens in case of autoimmune organ damage in mothers, which leads to upset gastrointestinal tract, indigestion, impaired enzyme formation and slowing down of enzymatic processes, intoxication and intoxication, the appearance of diarrhea [15].

All newborn calves were fed the first portion of freshly milked colostrum from mother cows when the sucking reflex appeared within two hours after birth. We found that cows with a homozygous genotype for allele B had the highest colostrum density (tab. 2), which averaged 1.067, which corresponded to the content of immunoglobulins of $106.7 \mathrm{mg} / \mathrm{l}$. After the first feeding of colostrum, after 24 hours, blood was taken from the calves and the 
amount of immunoglobulins was determined. In calves obtained from cows of genotype BB of the kappa-casein gene, the amount of immunoglobulins in the blood serum of day-old calves averaged $5.8 \mathrm{~g} / \mathrm{dl}$.

Table 2. The amount of immunoglobulins in cow colostrum and calf blood serum.

\begin{tabular}{|c|c|c|}
\hline Genotypes & $\begin{array}{l}\text { The amount of } \\
\text { immunoglobulins in colostrum, } \\
\mathrm{mg} / 1\end{array}$ & $\begin{array}{c}\text { The amount of immunoglobulins in the } \\
\text { blood serum of calves, } \mathrm{g} / \mathrm{dl}\end{array}$ \\
\hline $\mathrm{BB}$ & $106.7 \pm 0.1^{* * *}$ & $5.8 \pm 0.1^{* *}$ \\
\hline $\mathrm{AB}$ & $97.8 \pm 0.1^{* *}$ & $5.6 \pm 0.1^{*}$ \\
\hline $\mathrm{AA}$ & $77.2 \pm 0.1$ & $5.2 \pm 0.1$ \\
\hline
\end{tabular}

In fresh cows with the most common frequency of the AB genotype of the kappa-casein gene, the relative density of colostrum was within 1.064, which corresponded to the content of immunoglobulins in colostrum of $97.8 \mathrm{mg} / \mathrm{l}$. The amount of immunoglobulins in the blood serum of these newborn calves by the end of the first day of life averaged $5.6 \mathrm{~g} / \mathrm{dl}$.

The motor activity of newborn calves obtained from mothers with genotypes BB and $\mathrm{AB}$ of the kappa-casein gene was better expressed in the first hours after birth. They, on average, 18 minutes earlier than their peers received from mothers with the AA genotype of the kappa-casein gene, exhibited a sucking reflex, rose to their feet more actively, and reacted faster to external stimuli. As they grew and developed, these calves began to eat the proposed feeding earlier, no problems with disturbance of the gastrointestinal tract were observed throughout the experiment, and the safety of the calves was $100 \%$.

In cows with homozygous genotype A of the kappa-casein gene, the relative density of colostrum was slightly lower and averaged 1.057, and the amount of immunoglobulins was $29.5(\mathrm{P}>0.999)$ and $20.6 \mathrm{mg} / \mathrm{l}(\mathrm{P}>0.99)$ less than in cows of mothers with genotypes $\mathrm{BB}$ and $\mathrm{AB}$ of the kappa-casein gene. A decrease in the amount of immunoglobulins in colostrum resulted in a decrease in the amount of immunoglobulins in the blood of calves by 0.6 and $0.4 \mathrm{~g} / \mathrm{dL}$ in comparison with analogs of young animals obtained from cows with $\mathrm{BB}$ and $\mathrm{AB}$ genotypes. A decrease in immunoglobulins in the blood serum of calves resulted in gastrointestinal upset in $12 \%$ of the calves born. The disease manifested itself in a decrease in appetite: the calves fiddled with the teat drinker, while milk consumption either did not occur or was not consumed in full. In such calves, an increase in the temperature in the oral cavity was noted, although the overall temperature was within the physiological norm. In the future, they noted an increase in the frequency and liquefaction of fecal masses. The calves lay for a long time with their eyes half-closed, with their heads stretched out or laid on their stomachs, they reacted poorly to external stimuli, pain was noted on palpation of the abdominal wall. The high incidence of morbidity in calves obtained from cows of mothers with a homozygous genotype for the allele A of the kappacasein gene confirms the low efficiency of colostral immunity formation due to the low density of colostrum, and, consequently, the insufficient content of immunoglobulins in colostrum.

Thus, a direct relationship has been established between the content of immunoglobulins in the blood serum of calves and its presence in the colostrum of mothers cows. It follows from this that the higher the level of immunoglobulins in colostrum, the higher the amount of immunoglobulins in the blood of newborn calves, and therefore the higher the body's protective response to the action of opportunistic and pathogenic microflora. 
The live weight of calves obtained from cows with the BB genotype of the kappa-casein gene at birth was 3.1 and $0.34 \mathrm{~kg}$ more than their peers obtained from cows with the AA and $\mathrm{AB}$ genotypes of the kappa-casein gene.

The growth and development of young animals in the postnatal period depends on the dynamics of growth, development and nutritional status. The results show that the growth rate of calves obtained from cows of different genotypes was significantly different. Thus, the dynamics of the live weight of calves (tab. 3), obtained from cows of mothers with the AA genotype of the kappa-casein gene, during the first 30 days of life was $6.34(\mathrm{P}>0.99)$ and $4.78 \mathrm{~kg}(\mathrm{P}>0.95)$ lower than in young cows with genotype $\mathrm{BB}$ and $\mathrm{AB}$ of the kappacasein gene. A higher growth rate was characteristic in the first month of life for calves obtained from cows of mothers with a homozygous genotype for the B allele of the kappacasein gene, as a result of which the absolute weight gain was $3.1 \mathrm{~kg}$ higher than in young animals obtained from cows with a homozygous genotype for allele A of the kappa-casein gene.

Table 3. Growth rate of calves in the early postnatal period.

\begin{tabular}{|c|c|c|c|}
\hline Genotype & AA & AB & BB \\
\hline \multicolumn{4}{|c|}{ Live weight dynamics, kg } \\
\hline At birth & $28.46 \pm 1.18$ & $31.28 \pm 1.14$ & $31.62 \pm 1.10$ \\
\hline At 30 days & $48.64 \pm 1.24$ & $53.76 \pm 1.36^{*}$ & $54.98 \pm 1.48^{* *}$ \\
\hline \multicolumn{4}{|c|}{ Absolute weight gain, kg } \\
\hline $1-30$ & $20.18 \pm 1.21$ & $22.48 \pm 1.25$ & $23.36 \pm 1.76$ \\
\hline \multicolumn{4}{|c|}{ Daily gain, g } \\
\hline $1-30$ & $672 \pm 24$ & $749 \pm 30$ & $778 \pm 26$ \\
\hline
\end{tabular}

$\mathrm{P}>0.95^{*} ; \mathrm{P}>0.99^{* *} ; \mathrm{P}>0.999^{* * *}$

Between young animals obtained from cows of mothers with genotypes $\mathrm{AB}$ and $\mathrm{BB}$ of the kappa-casein gene, the difference in absolute growth was insignificant and amounted to $0.88 \mathrm{~kg}$ in favor of calves obtained from cows of mothers with genotype BB of the kappacasein gene.

In the study of morphological parameters of blood in all newborn calves after calving on the 3rd day of the study, physiological leukocytosis and erythrocytosis of newborns were noted.

Table 4. Morphological parameters of the blood of calves.

\begin{tabular}{|l|c|c|c|}
\hline \multirow{2}{*}{ Indicators } & \multicolumn{3}{|c|}{ Calves obtained from mothers of different genotypes } \\
\cline { 2 - 4 } & $\mathrm{AA}$ & $\mathrm{AB}$ & $\mathrm{BB}$ \\
\hline & \multicolumn{3}{|c|}{3 days after birth } \\
\hline $\mathrm{RBC}, 10^{12} / 1$ & $9.1 \pm 0.2$ & $9.3 \pm 0.1$ & $9.2 \pm 0.2$ \\
\hline $\mathrm{Hb}, \mathrm{g} / 1$ & $102.4 \pm 0.6$ & $112.4 \pm 0.6^{* *}$ & $113.6 \pm 0.7 * *$ \\
\hline $\mathrm{WBC}, 10^{9} / 1$ & $12.6 \pm 0.1$ & $12.2 \pm 0.1$ & $12.8 \pm 0.2$ \\
\hline & \multicolumn{3}{|c|}{ After 30 days } \\
\hline $\mathrm{RBC}, 10^{12} / 1$ & $5.4 \pm 0.1$ & $6.9 \pm 0.1^{* *}$ & $7.1 \pm 0.1 * * *$ \\
\hline $\mathrm{Hb}, \mathrm{g} / 1$ & $114.6 \pm 0.8$ & $120.4 \pm 1.1^{* *}$ & $122.2 \pm 0.9^{* *}$ \\
\hline $\mathrm{WBC}, 10^{9} / 1$ & $7.4 \pm 0.2$ & $8.2 \pm 0.2^{* *}$ & $8.6 \pm 0.1^{* * *}$ \\
\hline
\end{tabular}

$\mathrm{P}>0.95^{*} ; \mathrm{P}>0.99 * * ; \mathrm{P}>0.999^{* * *}$

At the age of one month, these indicators were within the normal range. However, it should be noted that the number of leukocytes in calves obtained from mothers of the AA genotype of the kappa-casein gene was 10.8 and $16.2 \%$ less than the indices of calves obtained from cows of the $\mathrm{AB}$ and $\mathrm{BB}$ genotypes of the kappa-casein gene.

Hemoglobin, being a respiratory blood pigment involved in the transport of oxygen and carbon dioxide and performing its buffer functions, was in calves obtained from cows with 
a homozygous genotype for allele A of the kappa-casein gene by 10.5 and $10.7 \%$ lower than in peers obtained from cows $\mathrm{AB}$ and $\mathrm{BB}$ genotype. The hemoglobin content in the blood of calves obtained from cows of genotype $\mathrm{AB}$ and $\mathrm{BB}$ did not have significant differences, however, it was higher by $1.8 \mathrm{~g} / \mathrm{l}$ in favor of calves obtained from cows of mothers with homozygous genotype for allele B of the kappa-casein gene.

\section{Conclusion}

1. The results of DNA genotyping indicated a low percentage of animals with the BB kappa-casein genotype, although this genotype has a high content of immunoglobulins in colostrum.

2. The density of colostrum in cows with a homozygous genotype for the B allele of the kappa-casein gene was higher compared to the homozygous genotype for the A allele and had a higher amount of immunoglobulins by $29.5 \mathrm{mg} / \mathrm{l}$, respectively.

3. The absence of morbidity in young animals throughout the experiment was noted in calves obtained from cows with genotypes $\mathrm{AB}$ and $\mathrm{BB}$ of the kappa-casein gene, which is associated with the formation of high colostral immunity of calves, as a result of their consumption of colostrum, which has a high density and, as a result, contains a greater amount of immunoglobulins.

4. For the prevention of diseases of the gastrointestinal tract in LLC "Leninskoe Znamya" it is necessary to form a herd of dairy cows with the genotype BB of the kappacasein gene.

5. The dynamics of the live weight of calves obtained from cows of mothers with the AA genotype of the kappa-casein gene, during the first 30 days of life, was 6.34 and 4.78 $\mathrm{kg}$ lower than in young cows with the BB and AB genotypes of the kappa-casein gene.

6. At the age of one month, the leukocyte content in calves obtained from cows from mothers with a homozygous genotype for allele A of the kappa-casein gene was less by 10.8 and $16.2 \%$, and hemoglobin by 10.5 and $10.7 \%$.

\section{Acknowledgment}

We express our deep gratitude to the organizers of the international scientific-practical conference "Innovative technologies in engineering and agroecosystems".

\section{References}

1. V. A. Bagirov, Sh. N. Nasibov, P. M. Klenovitsky, S. A. Lesin, et al, Reports of the Russian Academy of Agricultural Sciences, 37 (2010)

2. G. M. Dzhaparidze, Ya. A. Khabibrakhmanova, L. A. Kalashnikova, Actual problems of genetics and molecular biology in the framework of the Festival of Science, 125 (2012)

3. N. A. Zinovieva, O. V. Kostyunina, E. A. Gladyr, A.D. Bannikova, et al, Zootechniya, 8 (2010)

4. N. A. Zinovieva, S. V. Pozyabin, R. Yu. Chinarov, Agricultural Biology, 209 (2016)

5. A. A. Sermyagin, E.A. Gladyr, S. N. Kharitonov, A. N. Ermilov et al, Agricultural Biology, 182 (2016)

6. L. N. Chizhova, E. S., Surzhikova, M. V., Zabelina, E. D. Lutsiva, N. I. Efimova, Agrarian Scientific Journal, 75 (2020) 
7. I. V. Lazebnaya, O. E. Lazebnyi, V. F. Maximenko, G. E. Sulimova, Agricultural Biology, 39 (2012)

8. M. I. Selionova, Bulletin AIC, 21 (2011)

9. S. V. Tyulkin et al, Scientific notes of the Kazan State Academy of Veterinary Medicine named after N. E. Bauman, 221 (2015)

10. G. E. Sulimova, Electronic Journal of the Laboratory of Comparative Animal Genetics (2004) http://www. lab-cga.ru

11. M. Ernst, J. Kuciel, T. Urban, Czech J. Anim. Sci, 533 (2003)

12. M. I. Selionova, Bulletin AIC Stavropol, 21 (2011)

13. E. M. Prinzenberg, H. Jianlin, G. Erhardt, J. Dairy Sci., 1198 (2008)

14. E. G. Medvedeva, V. I. Tsys, Bulletin of the Upper AIC, 18 (2008)

15. O. N. Polozyuk, V. A. Kavalerist, E. S. Polozyuk, T. M. Ovcharenko, Proceedings of the Kuban Agrarian University, 74 (2014) 